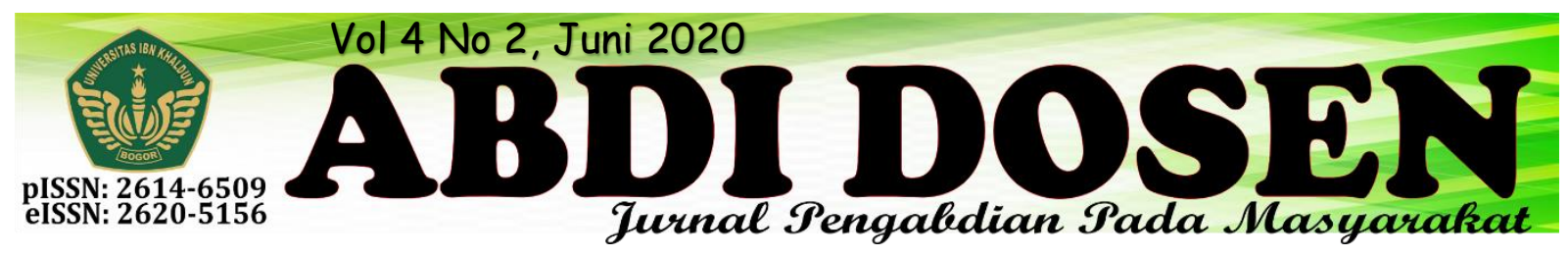

\title{
PEMANFAATAN HASIL LOKAL KP. PONCOL UNTUK PENGEMBANGAN USAHA RUMAHAN (PEMBUATAN KERIPIK SINGKONG)
}

\author{
Ahmad Shobari ${ }^{1}$, Gusti Naufal Taqy ${ }^{2}$ \\ ahmadshobari@uika-bogor.ac.id ${ }^{1}$ \\ gustinaufal04@gmail.com ${ }^{2}$ \\ Fakultas Agama Islam Universitas Ibn Khaldun ${ }^{1}$, Mahasiswa KKN Kelompok 11 Tahun $2018^{2}$
}

\begin{abstract}
ABSTRAK
Singkong merupakan umbi yang cukup tinggi konsumsinya. Singkong mempunyai sumber gizi, yaitu: Kalori 121 kal, Air 62,50 gram, Fosfor 40,00 gram, Karbohidrat 34,00 gram, Kalsium 33,00 miligram, Vitamin C 30,00 miligram, Protein 1,20 gram, Besi 0,70 miligram, Lemak 0,30 gram, Vitamin B1 0,01 miligram. Keripik yang sering dijumpai ditoko kelontong dan minimarket atau supermarket dianggap sebagai makanan ringan, dimana makanan ringan adalah makanan yang paling banyak peminatnya dari kalangan tua maupun muda. banyaknya inovasi Keripik singkong memberi peluang kepada masyarakat untuk memanfaatkan hasil bumi yang di hasilkan oleh daerahnya. Metode promosi yang akan di gunakan adalah dari mulut media cetak seperti pamflet, banner dan promosi ke media sosial seperti facebook, instagram dan lain sebagainya. Produk keripik singkong dalam 1 hari 30pcs, dengan penjualan 1pcs keripik singkong Rp.5000, maka penerimaan setiap hari akan di peroleh Rp. 150.000 dalam 1 bulan produksi 900pcs keripik singkong dengan omset yang akan di peroleh setiap bulan $\mathrm{Rp}$ 4.500.000. Pengemasannya menggunakan pelastik standing pouch karena lebih efisien dan mudah untuk langsung dikonsumsi.
\end{abstract}

Kata Kunci: Gizi, singkong, Peluang usaha.

\section{PENDAHULUAN}

\section{Latar Belakang}

Ketela pohon, ubi kayu, atau singkong (Manihot utilissima) adalah perdu tahunan tropika dan subtropika dari suku Euphorbiaceae. Umbinyadikenal luas sebagai makanan pokok penghasil karbohidrat dan daunnya sebagai sayuran.

Perdu, bisa mencapai 7 meter tinggi, dengan cabang agak jarang. Akar tunggang dengan sejumlah akar cabang yang kemudian membesar menjadi umbi akar yang dapat dimakan. Ukuran umbi ratarata bergaris tengah $2-3 \mathrm{~cm}$ dan panjang 50-80 cm, tergantung dari klon/kultivar.
Bagian dalam umbinya berwarna putih atau kekuning-kuningan. Umbi singkong tidak tahan simpan meskipun ditempatkan di lemari pendingin. Gejala kerusakan ditandai dengan keluarnya warna biru gelap akibat terbentuknya asam sianida yang bersifat meracun bagi manusia.

Umbi ketela pohon merupakan sumber energi yang kaya karbohidrat namun sangat miskin protein. Sumber protein yang bagus justru terdapat pada daun singkong karena mengandung asam amino metionina. 
Manihot esculenta pertama kali dikenal di Amerika Selatan kemudian dikembangkan pada masa prasejarah di Brasil dan Paraguay, sejak kurang lebih 10 ribu tahun yang lalu. Bentuk-bentuk modern dari spesies yang telah dibudidayakan dapat ditemukan bertumbuh liar di Brasil selatan. Meskipun spesies Manihot yang liar ada banyak, semua kultivar $M$. esculenta dapat dibudidayakan. Walaupun demikian, buktibukti arkeologis budidaya singkong justru banyak ditemukan di kebudayaan Indian Maya, tepatnya di Meksiko dan El Salvador.

Produksi singkong dunia diperkirakan mencapai 192 juta ton pada tahun 2004. Nigeria menempati urutan pertama dgn 52,4 juta ton, disusul Brasil dgn 25,4 juta ton. Indonesia menempati posisi ketiga dgn 24,1 juta ton, diikuti Thailand dgn 21,9 juta ton (FAO: 2004) Sebagian besar produksi dihasilkan di Afrika 99,1 juta ton dan 33,2 juta ton di Amerika Latin dan Kepulauan Karibia.

Singkong ditanam secara komersial di wilayah Indonesia (waktu itu Hindia Belanda) pada sekitar tahun 1810 (Cereda:1996), setelah sebelumnya diperkenalkan orang Portugis pada abad ke-16 dari Brasil. Menurut Haryono Rinardi dalam Politik Singkong Zaman Kolonial, singkong masuk ke Indonesia dibawa oleh Portugis ke Maluku sekitar abad ke-16. Tanaman ini dapat dipanen sesuai kebutuhan. "Sifat itulah yang menyebabkan tanaman ubi kayu seringkali disebut sebagai gudang persediaan di bawah tanah," tulis Haryono.

Butuh waktu lama singkong menyebar ke daerah lain, terutama ke Pulau Jawa. Diperkirakan singkong kali pertama diperkenalkan di suatu kabupaten di Jawa Timur pada 1852. "Bupatinya sebagai seorang pegawai negeri harus memberikan contoh dan bertindak sebagai pelopor. Kalau tidak, rakyat tidak akan mempercayainya sama sekali," tulis Pieter Creutzberg dan J.T.M. van Laanen dalam Sejarah Statistik Ekonomi Indonesia. ${ }^{\text {[butuh }}$ rujukan]

Namun hingga 1876, sebagaimana dicatat H.J. van Swieten, kontrolir di Trenggalek, dalam buku De Zoete Cassave (Jatropha janipha) yang terbit 1875 , singkong kurang dikenal atau tidak ada sama sekali di beberapa bagian Pulau Jawa, tetapi ditanam besar-besaran di bagian lain. "Bagaimanapun juga, singkong saat ini mempunyai arti yang lebih besar dalam susunan makanan penduduk dibandingkan dengan setengah abad yang lalu," tulisnya, sebagaimana dikutip Creutzberg dan van Laanen. Sampai sekitar tahun 1875, konsumsi singkong di Jawa masih rendah. Baru pada permulaan abad ke-20, konsumsinya meningkat pesat. Pembudidayaannya juga meluas. Terlebih rakyat diminta memperluas tanaman singkong mereka.

Peningkatan penanaman singkong sejalan dengan pertumbuhan penduduk Pulau Jawa yang pesat. Ditambah lagi produksi padi tertinggal di belakang pertumbuhan penduduk. "Singkong khususnya menjadi sumber pangan tambahan yang disukai," tulis Marwati Djoened Poesponegoro dan Nugroho Notosusanto dalam Sejarah Nasional Indonesia V. Hingga saat ini, singkong telah menjadi salah satu bahan pangan yang utama, tidak saja di Indonesia tetapi juga di dunia. Di Indonesia, singkong merupakan makanan pokok ketiga setelah padi-padian dan jagung.

Hindia Belanda pernah menjadi salah satu pengekspor dan penghasil tepung tapioka terbesar di dunia. Di Jawa banyak 
sekali didirikan pabrik2 pengolahan singkong untuk dijadikan tepung tetapioka. Seperti dalam buku Handbook of the Netherlands East Indies, pada tahun 1928 tercatat $21,9 \%$ produksi tetapioka diekspor ke Amerika Serikat, $16,7 \%$ ke Inggris, $8,4 \%$ ke Jepang, lalu $7 \%$ dikirim ke Belanda, Jerman, Belgia, Denmark dan Norwegia. Biasanya tepung olahan singkong tersebut dimanfaatkan sebagai bahan baku lem dan permen karet, industri tekstil dan furniture.

Singkong adalah nama lokal di kawasan Jawa Barat untuk tanaman ini. Nama "ubi kayu" dan "ketela pohon" dipakai dalam bahasa Melayu secara luas. Nama "ketela" secara etimologi berasal dari kata dalam bahasa Portugis "castilla" (dibaca "kastiya"), karena tanaman ini dibawa oleh orang Portugis dan Castilla (Spanyol)

\section{Kondisi Umum Lingkungan}

Indonesia terkenal sebagai negara agraris karena sebagian besar penduduk Indonesia bermata pencaharian sebagai petani. Indonesia mempunyai iklim tropis sehingga banyak tanaman dapat tumbuh dengan baik contohnya singkong. Singkong sangat populer di Indonesia, khususnya di wilayah Jawa Barat, yang menggunakan singkong sebagai bahan pokok, maka tidak heran masyarakatnya memiliki struktur tulang yang kuat dan besar karena banyak mendapatkan kalsium dari Ubi jalar tersebut. Daerah sentra produk ubi jalar pada mulanya terpusat dipulau jawa, terutama dikabupaten Bogor, Garut dan Bandung.

Komposisi yang terkandung dari bahan makanan singkong ini memberi alternatif sumber bahan pangan ringan rendah kalori dibanding makanan riangan yang lainnya.
Tingkat harga singkong yang rendah dan terjangkau oleh lapisan masyarakat indonesia menjadi salah satu faktor penting untuk mendorong usaha diversifikasi pangan ringan selain makanan riangan olahan seperti kerupuk. Singkong juga memiliki nilai ekonomis tinggi jika di olah mencapai produk yang tepat yang dapat memenuhi keinginan konsumen.

Seiring berkembangnya ilmu pengetahuan dan teknologi berbagai macam produk di ciptakan untuk memenuhi keinginan konsumen bahkan produk instan yang tidak sehat. Inovasi produk yang akan di kembangkan adalah kripik singkong. Bahan pokok yang digunakan

adalah singkong. Untuk pembuatan keripik singkong ini menggunakan singkong lokal. Keripik singkong yang dikenal masyarakat yaitu tidak berperasa, namun dalam pembuatan Keripik singkong ini kami tambahkan bumbu perasa seperti balado, BBQ, keju dll.

\section{Peluang Pasar}

Banyaknya penggemar penggemar makanan ringan membuat keripik singkong diyakini akan diminati oleh konsumen dari kalangan anak-anak sampai orang dewasa. Selain enak singkong juga memiliki Kelebihan yaitu Kalori, Air, Fosfor, Karbohidrat, Kalsium, Vitamin C, Besi, Lemak, dll.

Keripik singkong yang sering dijumpai di toko atau swalayan dianggap sebagai makanan ringan yang membosankan, dimana keripik singkong yang biasanya tidak memiliki rasa atau varian rasa, hanya menawarkan rasa original saja. Dan singkong sekarang jarang sekali dikonsumsi oleh masyarakat karena tidak ada olahan makanan yang berbeda, sehingga masyarakat menjadi bosan. Maka kami membuat ide ini untuk 
menciptakan inovasi baru terhadap singkong agar selalu dikenal oleh masyarakat bahwa singkong bisa dikemas sebagai makanan ringan yang modern.

\section{Analisis Ekonomi}

Produk Kripik singkong ini dalam 1 hari $\leq$ 30pcs, dengan penjualan 1pcs keripik singkong Rp.5000, maka

\section{METODE PENGABDIAN DAN HASIL}

Metode yang digunakan dalam program KKN ini terbagi atas 3 tahap, yaitu persiapan, cara kerja atau tahapan pekerjaan, pelaksanaan kegiatan dan evaluasi.

\section{a. Persiapan}

1. Persiapan Bahan dan Alat Tahap awal untuk pembuatan keripik singkong yaitu dengan mempersiapkan bahan seperti singkong, bumbu perasa, garam, minyak goreng. Setelah mempersiapkan bahan selanjutnya menyiapkan alat seperti timbangan, pisau, telenan, mangkuk, baskom, sendok, kompor, dan wajan. 2. Persiapan tempat tahap awal untuk persiapan tempat yaitu menentukan target pasar berdasarkan ketertarikan konsumen terhadap produk Keripik Sidang (singkong dangdeur). Jika target pasar sudah di

ketahui maka langkah selanjutnya survey tempat yang akan di jadikan tempat untuk memasarkan produk kita. Tempat yang akan menjadi target kita adalah pasar dan akan di promosikan di swalayan kecil di sekitar tempat tinggal. 3. Persiapan promosi produk Tahap awal untuk promosi produk yaitu menentukan strategi yang akan di gunakan untuk produk Keripik Sidang. Promosi pertama melalui lingkungan warga sekitar, promosi kedua dengan membuat brosur dan memperkenalkan di sosial media dan promosi ketiga dengan memperkenalkan penerimaan setiap hari akan di peroleh Rp. 150.000 dalam 1 bulan produksi 900pcs keripik singkong dengan omset yang akan di peroleh setiap bulan Rp 4.500.000. Pengemasannya menggunakan pelastik standing pouch karena lebih efisien dan mudah untuk langsung dikonsumsi. produk Keripik Sidang langsung dengan menitipkan produk di warung sekitar lingkungan atau di tempat tempat seperti sekolah sekolah.

\section{b. Pelaksanaan Program}

Bahan- bahan :

o $10 \mathrm{~kg}$ singkong, kupas, rendam di air semalam o iris tipis o tuang minyak ke penggorengan o goreng singkong yang sudah di iris tipis o $1 / 2 \mathrm{sdm}$ air garam ke dalam minyak o goreng hingga garing bubuk Bahan Pelengkap :

o bumbu perasa

\section{c. Cara kerja}

kupas kulit singkong lalu rendam dengan air, iris singkong tipis tipis, kemudian panaskan minyak goreng, siapkan air garam, lalu goreng singkong yang sudah kita iris dan masukan secukupnya air garam yang sudah kita siapkan tadi. Tiriskan singkong yang sudah mulai kecoklatan. Dinginkan singkong lalu masukan singkong ke dalam toples bersama dengan bumbu perasa, kemudian aduk hingga merata, lalu masukan ke dalam kemasan yang sudah di sediakan.

Pengemasan Burger ubi ini dikemas menggunakan pelastik standing pouch dan diberi stiker atau lebel dari keripik sidang agar lebih menarik konsumen Satu pcs keripik sidang kami jual dengan harga Rp. 5.000,- 


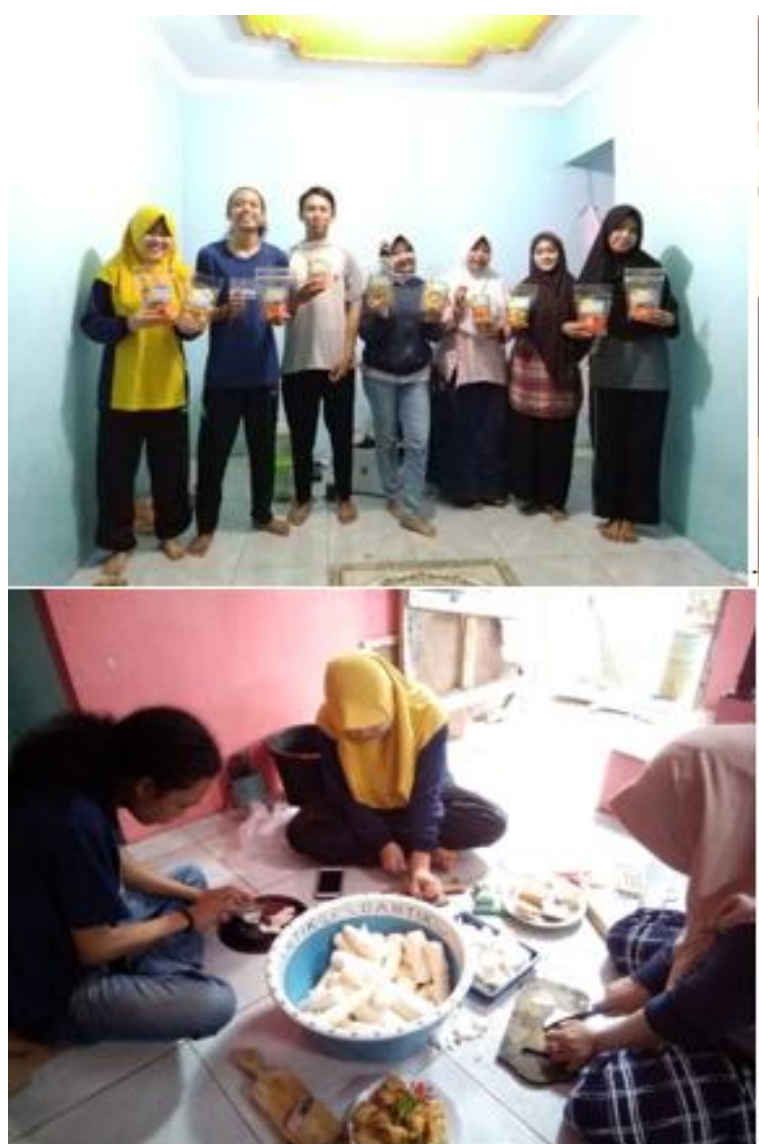

Penjualan Produk Keripik Sidang yang telah selesai melalui proses pengemasan dan sudah siap untuk di jual. Apapun metode penjualannya, hal yang terpenting adalah mutu produk harus baik, harga terjangkau, dan ketersediaan produk. Adapun metode strategi yang akan di gunakan adalah dari mulut mengenalkan produk menjunjung target pasar langsung

\section{KESIMPULAN}

Tujuan program

a. Memperkenalkan makanan ringan yang sehat sehat kepada masyarakat

b. Menumbuhkan jiwa kewirausahaan dikalangan warga sekitar

c. Meningkatkan ekonomi serta mengembangkan usaha rumahan warga sekitar

\section{Urgensi kegiatan usaha rumahan}

Cara pembuatan sangat mudah dan bahan baku pembuatan keripik ini relatif mudah didapatkan serta harga yang

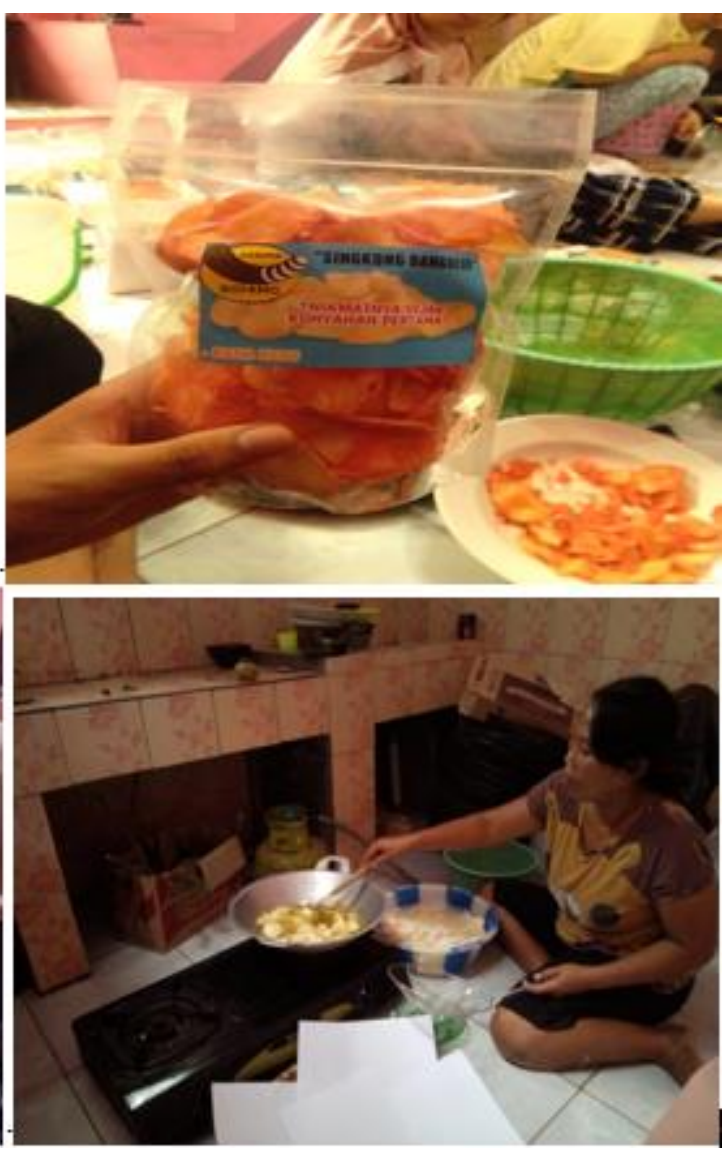

dan maka mengenalkan langsung produk kepada konsumen maupun distributor melalui media cetak seperti pamflet, banner, promosi ke media sosial seperti facebook, instagram dan lain nya. Kemudian program ini akan berjalan selama tiga bulan untuk dan mengetahui minat konsumen terhadap produk Keripik Sidang (singkong dangdeur).

terjangkau. Keripik singkong merupakan salah satu makanan favorit di kalangan anak muda jaman sekrang, serta prospek pasar keripik ini sangat menjanjikan. singkong adalah tanaman yang mudah di jumpai di kota bogor dengan penghasilan sangat besar. Oleh karena itu, kegiatan KKN Tematik Terintegrasi ini sangatlah penting bagi kami dalam berperan langsung dalam produksi keripik serta pemasarannya sebagai pelatihan mahasiswa di dunia bisnis. 


\section{Luaran manfaat yang diharapkan}

a. Terwujudkan sebuah usaha Keripik singkong home industri

b. Memberikan stimulus untuk menciptakan lapangan pekerja secara mandiri agar tercipta lapangan kerja berbasis potensial lokal.

\section{DAFTAR PUSTAKA}

https://id.wikipedia.org/wiki/Ketela_pohon

FAO, June 2003 cassava market assessment, 2003

Cereda, M.P. and Mattos, M.C.Y. (1996). "Linamarin - The Toxic Compound of Cassava". Journal of Venomous

\section{Manfaat program}

a. Menumbuhkan kreativitas mahasiswa dan warga untuk menciptkan inovasi produk terbaru

b. Menambahkan semangat jiwa kewirausahakan dan pengalaman mahasiswa

c. Memberi peluang usaha bagi warga sekitar.

Animals and Toxins (online) 2 (1), 612; ISSN 0104-7930

I. Sundarta, A. Sari and H. P. Wibowo, "Pengelolaan Limbah Organik Menjadi Kompos melalui Pembuatan Tong Super" Jurnal Pengabdian Pada Masyarakat, 2018. 